\title{
GERAKAN 30 SEPTEMBER 1965 DALAM PERSPEKTIF FILSAFAT SEJARAH MARXISME
}

\section{Harsa Permata}

Universitas Universal Batam

Email: harsa_permata@yahoo.com

\section{Abstrak}

Gerakan 30 September 1965 (G30S 1965), merupakan gerakan yang sangat berpengaruh bagi perkembangan gerak sejarah masyarakat Indonesia sampai saat ini. Setelah G30S 1965, kebebasan berideologi mulai dibatasi di Indonesia. Selain itu, pembantaian terhadap jutaan manusia, dengan alasan membasmi komunisme, mulai berlangsung setelah G30S 1965. Pembatasan terhadap kebebasan berideologi ini juga menyentuh kehidupan akademik. Berdasarkan atas TAP MPRS No. XXV/1966, studi terhadap ideologi Marxisme-Leninisme dibatasi. Hal ini mengakibatkan minimnya pemikiran alternatif dan ilmiah dalam dunia akademik di Indonesia. Gerakan 30 September 1965 (G30S 1965), ditinjau dari perspektif Marxisme, adalah perwujudan dari kontradiksi kelas dalam masyarakat Indonesia yang kapitalis. G30S 1965, memperjelas kontradiksi kelas dalam masyarakat Indonesia. Kelas-kelas sosial yang berkontradiksi dalam masyarakat Indonesia, adalah kelas borjuis militer yang diwakili oleh TNI (Tentara Nasional Indonesia), kelas proletariat, yang diwakili oleh PKI (Partai Komunis Indonesia). Presiden Sukarno, berada di tengah-tengah kontradiksi antara TNI dan PKI. Dalam perkembangannya, G30S 1965, dijadikan alasan oleh Suharto dan Angkatan Darat untuk melakukan kudeta merangkak terhadap pemerintahan Sukarno dan membantai jutaan orang kader dan simpatisan PKI. Pasca G30S 1965, rezim Orde Baru Suharto membuka pintu selebar-lebarnya bagi kapitalisme internasional, untuk mengeksploitasi sumber daya alam Indonesia. Rezim Orde Baru Suharto mematangkan kapitalisme di Indonesia.

Kata Kunci: Komunisme, Filsafat Sejarah, Marxisme.

\section{Abstract}

The Thirtieth of September Movement 1965 (G30S 1965), is a movement which is very influential in the history of Indonesian society until today. After G30S 1965, freedom of ideology began to be restricted in Indonesia. In addition, the slaughter of millions of human beings, with the reason to eradicate commu- 
nism, began to take place after G30S 1965. A restriction on freedom of ideology is also touching the academic life. Based on TAP MPRS No.. XXV/1966, the study of Marxism-Leninism ideology is limited. This resulted in the lack of alternative and scientific thought in the academic world in Indonesia. The Thirtieth of September Movement 1965 (G30S 1965), is the manifestation of class contradictions in the Indonesian capitalist society. G30S 1965, emphasize the class contradictions in Indonesian society. Social classes in Indonesian society, is a military bourgeoisie represented by the TNI (Indonesian Armed Forces), the proletariat, as represented by the PKI (Indonesian Communist Party). President Sukarno, was in the one who stand in the middle of the contradiction between the army and the PKI. And then, G30S 1965, used as an excuse by Suharto and the army to stage a creeping coup against President Sukarno and slaughtered millions of cadres and sympathizers of the PKI. After the G30S 1965, the New Order regime of Suharto opened the door wide open for international capitalism to exploit the natural resources of Indonesia. Suharto's New Order regime improves Indonesian capitalism.

Keywords: Communism, Philosophy of History, Marxism

\section{PENDAHULUAN}

Marxisme sebagai sebuah pandangan filsafat, cukup populer di Indonesia. Akan tetapi sangat sedikit orang yang memahami filsafat Marxisme secara menyeluruh. Hal ini karena terbatasnya sarana dan ruang untuk mempelajari Marxisme, terutama pandangan filsafat/ ideologi Marxisme-Leninisme. Keterbatasan ini terutama dikarenakan oleh pelarangan dari penguasa pasca Soekarno, atau Orde Baru melalui TAP MPRS No. XXV/1966. Munculnya TAP MPR ini disebabkan oleh sebuah gerakan yang berlangsung pada tanggal 30 September - 1 Oktober 1965. Gerakan ini dikenal juga sebagai gerakan 30 September 1965.

Pasca gerakan ini pluralitas ideologi di Indonesia mulai dibatasi, tidak hanya pembatasan terhadap pluralitas ideologi terutama ideologi Marxisme-Leninisme yang dilarang untuk dipelajari dan disebarkan-pembantaian jutaan manusia yang dituduh sebagai kader/simpatisan PKI (Partai Komunis Indonesia) juga terjadi pascaperistiwa tersebut. Diskursus tentang Marxisme di dunia akademik bahkan juga diba- 
tasi sesuai dengan isi dari TAP MPRS No.XXV/1966. TAP MPRS No. XXV tahun 1966 terdapat beberapa pasal yang membatasi pluralitas ideologi, khususnya di dunia akademik, pertama, "Setiap kegiatan di Indonesia untuk menyebarkan atau mengembangkan faham atau ajaran Komunisme/Marxisme-Leninisme dalam segala bentuk dan manifestasinya, dan penggunaan segala macam aparatur serta media bagi penyebaran atau pengembangan faham atau ajaran tersebut, dilarang" (Pasal 2 TAP MPRS No. XXV/MPRS/1966, 5 Juli 1966). “Khususnya mengenai kegiatan mempelajari secara ilmiah, seperti pada universitasuniversitas, faham Komunisme/Marxisme-Leninisme dalam rangka mengamankan Pancasila, dapat dilakukan secara terpimpin, dengan ketentuan bahwa Pemerintah dan DPR-GR diharuskan mengadakan perundang-undangan untuk pengamanan" (Pasal 3 TAP MPRS No. XXV/MPRS/1966, 5 Juli 1966).

Pasca jatuhnya pemerintahan Soeharto (Orde Baru), ketetapan ini tetap dinyatakan berlaku lewat Ketetapan MPR Nomor I/MPR/2003 yang berbunyi: “Ketetapan Majelis Permusyawaratan Rakyat Sementara Republik Indonesia Nomor XXV/MPRS/1966 tentang Pembubaran Partai Komunis Indonesia, Pernyataan Sebagai Organisasi Terlarang di Seluruh Wilayah Negara Republik Indonesia bagi Partai Komunis Indonesia dan Larangan Setiap Kegiatan untuk Menyebarkan atau Mengembangkan Faham atau Ajaran Komunis/Marxisme-Leninisme dinyatakan tetap berlaku dengan ketentuan seluruh ketentuan dalam Ketetapan Majelis Permusyawaratan Rakyat Sementara Republik Indonesia Nomor XXV/MPRS/1966 ini, ke depan diberlakukan dengan berkeadilan dan menghormati hukum, prinsip demokrasi dan hak asasi manusia" (id.wikipedia.org, 2011).

Selain itu, keluarga dari orang-orang yang dituduh sebagai kader /simpatisan PKI mengalami hidup yang sangat sulit. Mereka juga mengalami kesulitan dalam mencari pekerjaan sebagai PNS/TNI/ POLRI karena menemui keterbatasan, dengan adanya "syarat bebas Gerakan 30 September".

\section{SEJARAH GERAKAN 30 SEPTEMBER 1965}

Gerakan 30 September 1965 adalah sebuah gerakan yang sampai 
sekarang masih bersifat kontroversi. Ada berbagai pendapat dan kesaksian tentang G30S 1965, yang kemudian memunculkan berbagai versi G30S 1965. Setiap versi biasanya ada aktor utama yang memainkan peran sentral dalam gerakan 30 September 1965. Tiap-tiap versi memiliki aktor utama yang berbeda-beda. Seperti contoh, dalam versi Soeharto, yang menjabat sebagai presiden pada era Orde Baru, pemimpin utama G30S 1965 adalah Letkol Untung, yang juga adalah salah satu komandan Resimen Cakrabirawa, yang bertugas mengawal Presiden Soekarno. Sementara dalam versi TNI/ABRI, pemimpin utama G30S 1965 adalah ketua umum Partai Komunis Indonesia (PKI) yaitu D.N.Aidit.

Ada beberapa versi dalam sejarah tentang G30S 1965. Pemaparan keseluruhan versi juga bermanfaat untuk memahami esensi dan filsafat tersembunyi dari gerakan 30 September 1965. Ada beragam sudut pandang dalam deskripsi sejarah tentang G30S 1965.

\section{Versi Orde Baru}

Deskripsi sejarah Orde Baru terhadap G30S 1965 adalah berdasar atas dua otoritas sejarah, pertama adalah Soeharto sebagai pelaku sejarah, yang ikut membasmi G30S 1965. Kedua adalah TNI/ABRI, yang secara institusi juga terlibat dalam pembasmian G30S 1965. Walaupun ada sedikit perbedaan pada versi Soeharto dan TNI/ABRI dalam memandang G30S 1965, keduanya memiliki kesamaan pandangan bahwa PKI secara organisasional adalah pihak yang paling bersalah dalam gerakan 30 September 1965. Oleh karena itulah, Orde Baru menamai gerakan 30 September 1965 dengan singkatan G30S/PKI 1965. Seperti inilah kesaksian Soeharto tentang G30S 1965.

"Radio sudah disetel. Pukul 07.00 tepat saya mendengarkan siaran RRI pertama mengenai "Gerakan 30 September" yang dipimpin oleh Letkol Untung. Deg. saya segera mendapatkan firasat. Lagipula saya tahu siapa Letkol. Untung. Saya ingat, dia seorang yang dekat, rapat dengan PKI, malahan pernah jadi anak didik tokoh PKI, Alimin. Saya buka rapat itu dengan memberikan penjelasan mengenai situasi, 
mengenai siaran RRI pukul tujuh. "Saya banyak mengenal Untung sejak lama," kata saya. "Dan Untung sendiri sejak 1945 merupakan anak didik tokoh PKI Alimin." "Jadi yang dikatakan oleh Untung itu sama sekali tidak benar, " saya tegaskan. "Menurut saya, ini bukan sekadar gerakan untuk menghadapi apa yang dikatakan Dewan Jenderal saja, melainkan lebih jauh dari itu. Mereka mengadakan gerakan kup untuk merebut kekuasaan negara secara paksa. Dan pasti didalangi PKI." (Hadimadja \& Dwipayana, 1989: 119121).

TNI/ABRI agak sedikit berbeda dengan Soeharto, memandang bahwa D.N. Aidit adalah pemimpin tertinggi G30S 1965. Pandangan ini tertulis jelas dalam buku "Bahaya Laten Komunisme Di Indonesia", yang diterbitkan oleh Mabes ABRI tahun 1995. D.N. Aidit adalah figur sentral dalam G30S 1965 versi Mabes ABRI. Dalam menjalankan tugasnya sebagai pemimpin tertinggi G30S, Aidit yang dibantu oleh Iskandar Subekti, Pono, Kusno, dn Mayor Udara Sujono, bermarkas di Halim dari tanggal 30 September malam sampai tanggal 1 Oktober dini hari (Mabes ABRI, 1995: 180-181).

Sementara Mabes ABRI menuliskannya dalam buku "Bahaya Laten Komunisme di Indonesia”, yang berbunyi sebagai berikut, “Dalam gerakannya di Jakarta, G30S/PKI menyalahgunakan fasilitas-fasilitas AURI antara lain tempat, senjata, alat komunikasi, kendaraan dan bahkan pesawat udara untuk berbagai keperluan" (Mabes ABRI, 1995: 191). Kedua versi inilah yang kemudian dijadikan versi resmi Orde Baru dalam memandang Gerakan 30 September 1965. Versi resmi Orde Baru terhadap G30S, bisa dilihat dalam salah satu paragraf buku "Gerakan 30 September Partai Komunis Indonesia : Latar Belakang, aksi dan penumpasannya", yang diterbitkan oleh Sekretariat Negara Republik Indonesia di era Rezim Orde Baru, yang berbunyi sebagai berikut.

"Pada tanggal 4 Oktober 1965 itulah diketahui untuk pertama kalinya kejelasan mengenai "Gerakan 30 September" tersebut. Gerakan itu ternyata terkait dengan Partai Komu- 
nis Indonesia (PKI), yang sejak tahun 1951 membangun kembali kekuatannya setelah terlibat dalam pemberontakan terhadap Republik Indonesia dalam bulan September 1948 di kota Madiun, Jawa Timur" (SETNEG R.I, 1994: 3).

Versi resmi Orde Baru menganggap bahwa PKI sebagai dalang dan pelaku utama G30S 1965 adalah bertujuan untuk mengubah haluan negara Indonesia. Orde Baru memandang bahwa PKI bertujuan mengubah negara Indonesia yang berhaluan Pancasila, menjadi negara yang berhaluan komunis (SETNEG R.I, 1994: 167). PKI selain ingin mengubah haluan negara Indonesia juga dipandang akan selalu melaksanakan tujuan internasionalnya yaitu mengkomuniskan bangsa Indonesia (SETNEG R.I, 1994: 168).

\section{Versi Ben Anderson \& Ruth T. Mc Vey}

Ben Anderson dan Ruth T Mc Vey menuliskan analisis dan deskripsi mereka tentang G30S 1965 dalam sebuah buku yang berjudul “ $A$ Preliminary Analysis of the October 1, 1965 Coup in Indonesia". Analisis Anderson dan Mc Vey berfokus pada salah satu divisi dalam Angkatan Bersenjata Republik Indonesia, yaitu Divisi Diponegoro. Ini terlihat dalam paragraf awal buku tersebut, yang berbunyi sebagai berikut.

"The Seventh Division of the Indonesian Army, generally known as the Diponegoro Division, has always been the least approachable and most difficult to understand of the major territorial units of the Indonesian military. The reason for this is that it is the Division of Central Java, and fully reflects the complexities and withdrawn character of the civilization of this region. Like the Sixth (Siliwangi) Division in West Java and the Eighth (Brawidjaja) Division in East Java, Diponegoro is an integral part of the local landscape, and its internal structure and political tendencies closely mirror the society in which it is situated" (Anderson \& Mc Vey, 2009:15).

Fokus analisis Anderson dan Mc Vey terhadap Divisi Diponegoro yang berada di Jawa Tengah adalah sesuai dengan pandangan mereka 
bahwa G30S 1965 merupakan sebuah pemberontakan para perwira muda yang berasal dari Divisi Diponegoro dan daerah Jawa Tengah. Ini terlihat dalam salah satu paragraf analisis mereka terhadap G30S 1965, yang berbunyi sebagai berikut.

"The effective core of the September 30th Movement appears to have been a small group of "young officers" at the Semarang headquarters of the Diponegoro Division. These were 1) Col. Suherman, First Assistant to the Divisional Commander, in charge of Intelligence and Security for Central Java. 2) Col. Marjono, Third Assistant, in charge of personnel affairs. 3) Lieut-Col. Usman Sastrodibroto, Sixth Assistant, in charge of militarycontrolled civilian functional groups. Though they clearly had friends and sympathizers in other cities of Central Java, as we shall see, one does not have to assume that many officers were "in the know" at the beginning. In Djakarta there were Col. A. Latief, Commander of the First Infantry Brigade of the Fifth (Djaya) Territorial Command (the post involved control of a number of mobile battalions in the city of Djakarta); Lieut. Col. Untung, Commander of the First Battalion of the Tjakrabirawa Regiment (Bodyguards to the President); Brig. Gen. M. S. Supardjo, commander of the Fourth Combat Command in Mandau, West Kalimantan, and, among a number of sympathetic Air Force officers, Flight Major Sujono, Commander of the Guard at Halim Perdana Kusumah Airbase just outside Djakarta. A larger number of junior officers was also involved as it turned out, but the above mentioned seven seem to have been the most important figures" (Anderson \& Mc Vey, 2009: 22).

Menurut Anderson dan Mc Vey, salah satu bukti dari pendapat bahwa G30S 1965 adalah sebuah pemberontakan perwira muda yang berasal dari Jawa Tengah, adalah terletak pada komposisi tim inti dari G30S 1965. Tim inti G30S 1965, berdasarkan atas uraian Anderson dan Mc Vey adalah tentara-tentara muda yang berasal dari Divisi Diponegoro, Jawa Tengah. Walaupun secara teritorial, Latief, Untung, Supar- 
djo, dan Sujono, ketika peristiwa itu bukanlah tentara Divisi Diponegoro, keempat perwira tersebut tetap memiliki hubungan dengan Divisi Diponegoro, Jawa Tengah. Seperti Letkol. Untung, misalnya, dia pernah menjadi orang kepercayaan, Kolonel Suherman, semasa bertugas di Jawa Tengah dulu.

Letkol. Untung juga pernah menjabat sebagai komandan Batalyon 454, yang berada dalam Divisi Diponegoro (Anderson \& Mc Vey, 2009: 24). Menurut Anderson dan Mc Vey alasan pemberontakan para perwira muda tersebut adalah, pertama, karena ketidakpuasan mereka terhadap Staf Umum dan pimpinan militer di Jakarta, yang mereka anggap bergelimang kemewahan dan korup. Kedua, perang dingin antara Soekarno dengan SUAD (Staf Umum Angkatan Darat) yang dianggap kerap berkontak dengan CIA (Central Intelligence Agency/Agen rahasia Amerika Serikat), membuat para perwira muda ini meragukan patriotisme para Jenderal SUAD dan Jenderal-Jenderal pimpinan militer di Jakarta lainnya.

Selain itu menurut Anderson dan Mc Vey ada kemungkinan para perwira muda ini ingin mengembalikan semangat revolusioner 1945 dalam sistem politik Indonesia. Pembentukan Dewan Revolusi yang mirip dengan Komite Nasional Indonesia (KNI) adalah salah satu indikasinya. Menurut Anderson dan Mc Vey alasan utama pemberontakan para perwira muda ini adalah karena didorong oleh semangat idealisme mereka sendiri (Anderson \& Mc Vey, 2009: 23-24).

\section{Versi Harold Crouch}

Menurut Harold Crouch, PKI terlibat dalam G30S 1965, walaupun indikasi keterlibatan PKI belum begitu jelas (Crouch, 2007: 101). Kehadiran Aidit di Bandara Halim pada tanggal 1 Oktober 1945 adalah salah satu indikasi keterlibatan PKI, menurut Harold Crouch. Selain itu, dukungan dari Gerwani (Gerakan Wanita Indonesia) dan PR (Pemuda Rakyat) yang berafiliasi dengan PKI terhadap G30S 1965 adalah indikasi lainnya dari keterlibatan PKI dalam G30S 1965. Indikasi keterlibatan berikutnya adalah editorial Harian Rakjat yang berisikan pujian terhadap G30S 1965. Harian Rakjat adalah koran PKI. Indikasi 
utama keterlibatan PKI dalam G30S 1965, menurut Harold Crouch adalah pengakuan pimpinan PKI, Njono di Harian Angkatan Bersenjata dan pengakuan Aidit yang dipublikasikan oleh pers Jepang pada bulan Februari 1966. Kedua pengakuan tersebut menyatakan bahwa PKI berperan besar dalam G30S 1965. Akan tetapi, menurut Harold Crouch, PKI walaupun terlibat dalam G30S 1965 bukanlah dalang G30S 1965. Tidak ada bukti bahwa para perwira Angkatan Bersenjata seperti Untung dan Supardjo adalah agen PKI. Oleh karena itu, mereka bertindak bukanlah berdasarkan perintah Sjam (agen PKI dalam G30S 1965). Sementara itu, salah satu pelaku utama G30S 1965 yaitu Kolonel Suherman, yang merupakan anggota kelompok Jawa Tengah, telah dibunuh sebelum dimintai keterangan lebih lanjut. Selain itu, Kolonel Latief, sebagai salah satu pelaku utama yang merupakan perwira Jakarta, tidak pernah dibawa ke pengadilan. Menurut Harold Crouch, para perwira angkatan bersenjata yang terlibat dalam G30S 1965, bertindak karena kehendak mereka sendiri (Crouch, 2007: 104).

Crouch berpendapat bahwa PKI memang memiliki alasan untuk mendukung G30S 1965, yaitu karena ketakutan PKI akan kudeta Dewan Jenderal terhadap Soekarno. Kudeta tersebut diyakini PKI, akan membawa bencana bagi mereka. Akan tetapi, PKI tidak memiliki sumber daya yang cukup untuk melawan TNI/ABRI dalam konfrontasi langsung. Maksudnya, PKI tidak memiliki sayap bersenjata yang terlatih dan cukup kuat untuk mengadakan konflik terbuka dengan tentara. Menurut Crouch PKI lebih memilih solusi kup dalam bentuk konflik internal angkatan bersenjata, karena dengan begitu keterlibatan PKI menjadi tidak kelihatan (Crouch, 2007: 108).

Menurut Crouch salah satu pimpinan PKI yaitu Njono, memang mengakui bahwa ia memang mendukung pihak tentara pemberontak G30S, dengan cara merencanakan pelatihan militer bagi para anggota ormas PKI. Tujuannya adalah agar para anggota ormas yang dilatih ini kemudian menjadi pasukan cadangan, yang berfungsi sebagai bala bantuan bagi tentara profesional yang terlibat G30S 1965. Akan tetapi, Njono membantah bahwa PKI secara organisasional terlibat. Pimpinan PKI lainnya, seperti Sudisman dan Peris Pardede, menurut Crouch, 
memang mendukung kup G30S 1965, tetapi mereka menyatakan bahwa inisiatif kup berasal dari perwira progresif. Kesaksian Sjam, yang merupakan pimpinan biro khusus, menyatakan bahwa para tentara yang terlibat G30S 1965, telah dimanipulasi oleh PKI. Walaupun demikian, dalam pengadilan, keterlibatan PKI masih diperdebatkan (Crouch, 2007: 109).

Kesaksian Sjam dalam buku Harold Crouch, menyatakan bahwa Sjam dipanggil oleh Aidit ke rumahnya, pada tanggal 12 Agustus. Aidit mendiskusikan perihal kondisi Presiden Soekarno yang menderita sakit yang cukup serius, dan langkah yang mungkin diambil Dewan Jenderal, jika Presiden Soekarno wafat. Aidit mengatakan pada Sjam, bahwa informasi keberadaan Dewan Jenderal didapatnya dari Sakirman, salah seorang anggota Politbiro PKI, yang juga merupakan kakak dari Mayor Jenderal S. Parman, pimpinan intelijen angkatan bersenjata. Aidit kemudian meminta Sjam untuk menyusun kekuatan dan menyiapkan sebuah gerakan. Tanggal 13 Agustus, Sjam dan para anggota biro khusus lainnya, seperti Pono dan Walujo, mendiskusikan pelaku-pelaku yang mungkin melaksanakan sebuah gerakan. Akhirnya diputuskan untuk mendekati Kolonel Latief, salah seorang pimpinan brigade infanteri di Jakarta. Selain itu, mereka memutuskan untuk mendekati Letkol. Untung, yang merupakan komandan salah satu batalyon Cakrabirawa, pasukan pengawal presiden. Berikutnya adalah Mayor Sujono, yang merupakan komandan pertahanan udara Halim. Tiga orang ini didekati oleh biro khusus, adalah karena ketiganya bersimpati pada PKI. Ketiganya kemudian menyetujui langsung untuk bergabung dalam G30S (Crouch, 2007: 110).

Aidit kemudian menghubungi Mayor Sigit, salah seorang komandan batalyon dalam brigade infanteri pimpinan Kolonel Latief. Selain itu, Aidit menghubungi komandan pertahanan udara komando militer Jakarta, Kapten Wahjudi. Dalam perkembangannya Sigit dan Wahyudi mundur, dan para konspirator G30S 1965, berhasil merekrut Brigjend Supardjo, komandan pasukan tempur Kolaga (Komando Mandala Siaga) di Kalimantan, yang telah dikenal Sjam sejak pertengahan 1950-an (Crouch, 2007: 110). 
Seperti itulah pandangan Harold Crouch tentang G30S 1965, sebagai sebuah persekutuan rahasia antara para perwira progresif dengan biro khusus, divisi rahasia, PKI. Walaupun PKI terlibat, eksekutor di lapangan adalah para perwira progresif, karena tidak ada bukti cukup yang menyatakan bahwa para perwira progresif ini tunduk pada instruksi PKI. Para perwira ini menurut Crouch, walaupun bekerjasama dengan biro khusus, mereka memiliki tujuan sendiri (Crouch, 2007: 117).

\section{Versi W.F. Wertheim}

W.F. Wertheim berpendapat bahwa para pimpinan G30S 1965, seperti Letkol Untung, Sjam, dan Kolonel Latief, adalah kenalan Suharto. Kedekatan hubungan Untung dan Suharto, terlihat ketika Suharto pergi menghadiri pernikahan Untung di Kebumen, dari Jakarta, pada tahun 1964 (Roosa, 2008: 107). Sementara kedekatan Suharto dan Latief, bermula dari era perang gerilya pada akhir 1940-an. Bahkan sebagai seorang pelaku utama G30S, Latief tidak dieksekusi, tetapi dibiarkan hidup di penjara Orde Baru selama bertahun-tahun (Roosa, 2008: 108).

Dalam buku Harold Crouch, The Army and Politics in Indonesia, dijelaskan bahwa Wertheim mendeskripsikan hubungan Suharto dengan semua perwira TNI/ABRI yang terlibat dalam G30S 1965. Ketika menjabat sebagai Komandan Divisi Diponegoro, Untung adalah bawahan Suharto di Jawa Tengah, begitu juga Latief, yang sebelumnya pernah bertugas di Divisi Diponegoro, Jawa Tengah. Latief juga pernah semarkas dengan Suharto, ketika perang perebutan Irian Barat pada tahun 1964. Sementara Brigjend Supardjo, salah seorang pimpinan G30S 1965, adalah bawahan Suharto, ketika Suharto menjabat sebagai Komandan Divisi Komando Mandala Siaga (Kolaga) di Kalimantan (Crouch, 2007: 123). Bukti lainnya bahwa Suharto tidak termasuk ke dalam daftar Jenderal yang diculik pasukan G30S. Selain itu, Suharto bisa bergerak leluasa di Jakarta, pada waktu malam berlangsungnya operasi militer G30S. Suharto juga mengetahui cara untuk menaklukkan G30S dengan mudah, padahal para perwira militer yang berada di 
Jakarta, tidak paham harus mengambil tindakan apa untuk menghadapi operasi militer G30S (Roosa, 2008: 108).

Hubungan Suharto dengan Sjam, digambarkan oleh Wertheim sebagai hubungan sesama anggota TNI/ABRI. Menurut Wertheim, Sjam adalah intel tentara, yang ditugaskan untuk menyusup ke dalam PKI. Penyusupan Sjam ke tubuh PKI, adalah bertujuan untuk memprovokasi PKI, agar terlibat dalam sebuah aksi (G30S) yang direncanakan untuk gagal. Indikasi kedekatan Sjam dengan Suharto dan TNI/ABRI, menurut Wertheim adalah berdasarkan atas fakta bahwa Sjam bersikap kooperatif dengan pihak TNI/ABRI selama masa interogasi. Selain itu, Sjam tidak pernah disiksa dan mendapat perlakuan istimewa oleh para interrogator TNI/ABRI (Roosa, 2008: 108-109).

\section{Versi John Roosa}

John Rosa berpandangan bahwa G30S 1965 bukanlah sebuah aksi yang direncanakan oleh seorang atau sekelompok dalang. Lebih lengkapnya pendapat John Roosa berbunyi sebagai berikut.

"Kelemahan penyelidikan-penyelidikan tentang G30S terdahulu terletak pada titik tolak mereka: dugaan bahwa pasti ada dalang di balik gerakan itu. Menurut hemat saya tidak ada "otak" utama, apakah ia berupa seorang tokoh, ataukah suatu gugus rapat orang-orang yang terorganisasi mengikuti pembagian kerja serta hierarki kewenangan yang jelas. G30S menjadi bersifat misterius justru karena tidak adanya pusat pengambilan keputusan yang tunggal" (Roosa, 2008: 293).

Ketidakjelasan rantai komando dalam operasi militer G30S 1965, membingungkan salah seorang perwira pimpinan G30S 1965, yaitu Brigjend Suparjo. Tokoh pusat G30S 1965 dalam pemahaman Supardjo adalah Sjam, karena Sjam adalah penghubung antara Aidit dan para perwira TNI/ABRI pimpinan G30S. Akan tetapi, peran Sjam bukanlah sebagai seorang komandan operasi, melainkan hanya berperan sebagai mediator. 
Sebelum meletusnya Gerakan 30 September 1965, dalam perpolitikan Indonesia, menurut John Roosa, terdapat tiga kekuatan politik yaitu PKI, TNI Angkatan Darat (AD), dan Sukarno, yang berada di tengah-tengah kedua kubu yang saling bertentangan itu (TNI dan PKI) (Roosa, 2008: 296). Sukarno menjalankan politik keseimbangan untuk melanggengkan kekuasaannya. Sukarno membutuhkan PKI dan kekuatan massanya, untuk menaikkan posisi tawarnya ketika berhadapan dengan Angkatan Darat. Beberapa saat sebelum G30S, keseimbangan tersebut mulai berantakan, karena Sukarno mulai condong ke PKI, seiring dengan semakin besarnya PKI dan kekuatan massanya (Roosa, 2008: 297).

PKI sebagai salah satu kekuatan politik dominan pada masa pemerintahan Sukarno, mulai merasa tidak puas dengan kondisi politik pemerintahan Sukarno. Ketidakpuasan tersebut terutama terletak pada tiadanya komposisi menteri dalam kabinet pemerintahan Sukarno. Keberpihakan Sukarno tersebut terlihat ketika Sukarno menghukum para perwira Angkatan Darat yang membekukan cabang-cabang PKI di berbagai daerah, pada tahun 1960-an (Roosa, 2008: 297-298).

Desas-desus yang beredar sebelum G30S 1965 adalah bahwa Angkatan Darat akan melancarkan kup untuk menggulingkan pemerintahan Sukarno. Desas-desus tersebut berhembus karena beredarnya ke publik, sebuah telegram (yang masih diragukan keasliannya) dari Duta Besar Inggris untuk Indonesia kepada Kementerian Luar Negeri Inggris di London. Telegram tersebut menyebutkan tentang keberadaan personil TNI yang sedang melaksanakan satu aksi konspiratif. Dalam telegram tersebut, para personil TNI itu disebut sebagai "Kawankawan militer setempat kita". Atas dasar kondisi politik tersebut, Aidit sebagai ketua PKI, menginstruksikan Sjam, sebagai pimpinan biro khusus, divisi rahasia PKI, untuk menyelidiki kebenaran desas-desus tersebut. Berdasarkan hasil penyelidikannya dan biro khusus, Sjam melaporkan kesimpulannya pada Aidit, bahwa para Jenderal sayap kanan yang dipimpin oleh Ahmad Yani, akan melancarkan kup terhadap Presiden Sukarno (Roosa, 2008: 300-301). 
Hal ini membuat Aidit menimbang dua pilihan sikap, yaitu mendahului atau didahului. Ketika mempertimbangkan dua pilihan ini, Aidit mendiskusikan dengan Sjam, tentang langkah untuk menggerakkan para perwira progresif melawan para Jenderal sayap kanan yang tergabung dalam Dewan Jenderal. Sjam dan jaringan biro khususnya kemudian mengajak para perwira progresif untuk melakukan sebuah tindakan nyata melawan Dewan Jenderal. Oleh karena ketiadaan kepastian rencana, maka Sjam memutuskan memimpin sendiri aksi tersebut. Selanjutnya, Sjam berusaha menyakinkan para perwira tersebut bahwa rencana mereka tidak mungkin gagal (Roosa, 2008: 303).

Celakanya rencana yang sudah disusun mulai tidak sesuai dengan kenyataan yang berlangsung. Ketika para konspirator G30S 1965 lainnya mengkritik kelemahan rencana yang telah disusun, Sjam bersikeras untuk tetap melaksanakan rencana itu. Sikap Sjam ini berdasarkan atas keyakinannya terhadap kekuatan pendukung Sukarno dan massa PKI. Selain itu, Sjam tidak mau mengecewakan Aidit, yang merupakan pimpinannya (Roosa, 2008: 309). Karena persiapan yang tidak rapi, dan rantai komando yang tidak jelas, G30S 1965 kemudian menemui kegagalan. Kegagalan pertama adalah para pasukan yang bertugas untuk menculik para Jenderal, ternyata tidak bisa menculik para Jenderal tersebut dalam keadaan hidup. Karena rencana utama gagal, para pimpinan G30S 1965 memutuskan untuk menghabisi nyawa para perwira yang telah diculik (Roosa, 2008: 311).

Karena rencana utama gagal dilaksanakan, semua rencana lainnya, yang telah disusun juga gagal dilaksanakan. Sukarno tidak mau mendukung G30S 1965, setelah mengetahui kematian para perwira Angkatan Darat yang diculik oleh para pelaku G30S 1965. Sukarno memerintahkan Supardjo, yang berkesempatan untuk menghadap Sukarno, agar menghentikan aksi G30S 1965. Para perwira TNI yang terlibat G30S 1965, seperti Supardjo, Untung, Latief, dan Soejono menyetujui untuk menghentikan G30S 1965. Akan tetapi, Sjam dan Aidit, memutuskan untuk melanjutkan G30S 1965 tanpa persetujuan Sukarno, dengan menyerukan pembentukan Dewan-Dewan Revolusi melalui radio. Karena tiadanya kesamaan sikap antara Sjam dengan para 
perwira pimpinan G30S 1965, seruan pembentukan Dewan Revolusi tersebut tidak dikumandangkan dalam siaran radio pada pagi dan siang hari tanggal 1 Oktober 1965 (Roosa, 2008:312).

Sjam gagal mencoba meyakinkan para perwira pimpinan TNI, pimpinan G30S 1965. Sjam dan Aidit kemudian mengubah rencana mendukung pemerintahan Sukarno, menjadi menggantikan pemerintahan Sukarno. Oleh karena itulah maka dalam seruan pembentukan Dewan Revolusi yang telah dikumandangkan melalui stasiun RRI, pada sore harinya, terdapat konsep pendemisioneran kabinet pemerintahan Sukarno dan penyerahan kekuasaan negara pada Dewan Revolusi (Roosa, 2008:313).

Aidit kemudian meminta Sjam untuk mengajak para perwira progresif melancarkan aksi penculikan terhadap para jenderal sayap kanan, yang tergabung dalam Dewan Jenderal. Para perwira progresif itu menyetujui untuk melancarkan aksi G30S 1965, karena tujuan awal G30S 1965 untuk mendukung dan melindungi pemerintahan Sukarno dari kudeta Dewan Jenderal. Ketika rencana menculik para jenderal untuk dihadapkan pada Sukarno dalam keadaan hidup itu gagal, para perwira progresif tersebut memutuskan mundur dari aksi G30S 1965.

\section{Versi Rex Mortimer}

Rex Mortimer, dalam buku Indonesian Communism Under Sukarno, Ideology and Politics, 1959-1965, berpendapat bahwa G30S 1965 adalah sebuah hasil manipulasi terhadap PKI, oleh lawan politiknya, lebih lengkapnya pendapat Rex Mortimer berbunyi sebagai berikut.

"Construing this interpretation at its worst, then, the PKI leaders appear as the manipulated rather than the manipulators. Drawn into something they could not control (and in most cases did not even know enough about to make careful estimates), and more deeply implicated than they bad anticipated by the use made of their volunteers by the plotters, they were eventually placed at the mercy of the enemy they had so long striven to fend off. The party's apparent lack of control over the conspirators once more highlighted the perennial problem faced by the Communists: that, in a 
political situation where arms were the final arbiters, those with the guns dictated thee terms" (Mortimer, 2006: 440).

Alasan Mortimer adalah:

a. Transkrip sebuah rekaman semiresmi dari hasil interogasi dan pengumpulan bukti terkait plot G30S 1965. Transkrip tersebut tertulis bahwa tujuan PKI terkait aksi G30S 1965 adalah bukan untuk merebut kekuasaan politik, melainkan hanya untuk mencegah pelenyapan Partai Komunis Indonesia (PKI) oleh TNI Angkatan Darat, setelah wafatnya Sukarno (Mortimer, 2006: 419).

b. Ketidakadilan persidangan terhadap pelaku G30S 1965. Hal ini disebabkan oleh tidak adanya bukti yang jelas tentang pihak yang menyebarkan isu tersebut (Mortimer, 2006: 421-422).

c. Pendapat Angkatan Darat bahwa pelatihan para sukarelawan PKI di Halim adalah terkait dengan G30S 1965. Fakta di lapangan, komposisi para sukarelawan yang ikut pelatihan di Halim, ternyata bukan hanya berasal dari PKI, melainkan juga terdapat kelompok-kelompok yang bukan PKI, seperti Pemuda Marhaenis, Perti, dan Pertindo. Bahkan GP Anshor yang berasal dari pihak NU, dan terkenal antikomunis, juga dijadwalkan untuk mengikuti pelatihan tersebut pada tanggal 1 Oktober 1965 (Mortimer, 2006: 424).

d. Isi pengumuman G30S 1965 pada tanggal 1 Oktober pagi hari yang berbeda dengan sikap politik PKI dan pemerintahan Sukarno. Perbedaan utama terletak pada adanya seruan dalam pengumuman tersebut untuk mempertahankan kebijakan luar negeri Indonesia yang bersifat bebas dan aktif (Mortimer, 2006: 425).

e. Komposisi Dewan Revolusi yang diisi oleh tokoh-tokoh yang berseberangan dengan PKI. Tercatat ada 19 dari 45 tokoh yang berseberangan dengan PKI dalam Dewan Revolusi tersebut (Mortimer, 2006: 426).

f. Tuduhan yang mengaitkan empat pimpinan militer G30S 1965, yaitu Letkol Untung, Brigjend Supardjo, Kolonel Latief, dan Kolonel Sahirman, dengan PKI. Salah satunya adalah tuduhan bahwa Untung terlibat pemberontakan PKI Madiun tahun 1948. Fakta riil adalah bahwa Untung ketika itu belum paham politik dan bertindak 
sesuai komando dari komandannya yang antikomunis. Selanjutnya adalah Supardjo yang memiliki rekam jejak kemiliteran yang cemerlang. Supardjo yang merupakan seorang loyalis Sukarno, ternyata memiliki sikap politik anti PKI. Latief, jabatannya sebagai salah satu komandan militer TNI di Jakarta adalah bukti bahwa ia tidak memiliki kedekatan dengan PKI. Hal ini disebabkan oleh ketatnya seleksi di tubuh TNI Angkatan Darat yang anti PKI, dalam penempatan seorang perwira di sebuah posisi vital seperti komandan militer. Perwira terakhir adalah Kolonel Sahirman, fakta riil tentang Sahirman bahwa ia ditunjuk sebagai Kepala Seksi I (Intelijen) Staf Divisi Diponegoro, Semarang, Jawa Tengah, karena kapasitasnya sebagai seorang perwira TNI yang antikomunis (Mortimer, 2006: 427-429).

g. Keterkaitan Sjam dengan TNI. Berdasarkan atas keterangan salah seorang perwira Angkatan Darat, yang menangkap Sjam, diketahui bahwa Sjam telah bekerja sebagai informan Seksi I (intelijen) Resimen Jakarta Raya sejak tahun 1955. Lebih lanjut, perwira AD tersebut juga menyatakan bahwa pelarian Sjam selama 18 bulan, banyak dibantu oleh para komandan di batalyon tempat dia bertugas dulu. Keterangan perwira AD ini dimuat di Harian Sinar Harapan tanggal 13 Maret 1967 (Mortimer, 2006: 431).

\section{DAMPAK G30S 1965 TERHADAP KEHIDUPAN POLITIK, EKONOMI, DAN KEMANUSIAAN DI INDONESIA}

Sukarno melakukan langkah politik pembelaan terhadap PKI, melalui penghukuman terhadap para perwira $\mathrm{AD}$, yang membekukan cabang-cabang PKI pada tahun 1960 (Roosa, 2008: 297). Beberapa saat sebelum meletusnya Gerakan 30 September 1965, keseimbangan ini mulai goyah, sikap Sukarno, semakin pro PKI adalah salah satu pemicunya. Pelarangan terhadap Partai Murba yang anti PKI, dan pelarangan terbit terhadap berbagai surat kabar yang anti PKI adalah beberapa contoh keberpihakan Sukarno terhadap PKI (Ricklefs, 2001: 336). Akan tetapi pihak TNI sadar bahwa usaha penggulingan Sukarno secara terang-terangan adalah sia-sia karena popularitas Sukarno yang tinggi di mata rakyat (Roosa, 2008:300). 
Sebenarnya kedekatan Sukarno dengan PKI sudah terlihat semenjak tahun 1959. Hal ini terjadi karena PKI adalah pendukung sikap nasionalis militan Sukarno yang paling konsisten. Dengan dukungan PKI yang memiliki kekuatan massa yang cukup besar, Sukarno memiliki posisi tawar yang cukup kuat di hadapan TNI (militer) (Mortimer, 2006: 79). G30S 1965 adalah alasan bagi pihak TNI untuk mengambil langkah terang-terangan membasmi PKI. Aksi pembasmian G30S 1965 dan PKI, dipimpin oleh Suharto, salah seorang Jenderal Angkatan Darat. Pada pukul 18.00 WIB, tanggal 1 Oktober 1965, Suharto dan pasukannya telah berhasil merebut Lapangan Merdeka dan RRI. Melalui RRI, Suharto kemudian mengumumkan bahwa G30S 1965, adalah sebuah gerakan kontrarevolusioner (Roosa, 2008:317).

Pembasmian G30S 1965 oleh TNI/ABRI kemudian dilanjutkan dengan pembasmian PKI. Pada tanggal 7 Oktober 1965, rumah-rumah para anggota PKI dan sekretariat-sekretariat milik PKI dibakar dan dihancurkan oleh kelompok-kelompok Islam antikomunis. Kejadian inilah yang kemudian mengispirasi pembasmian golongan komunis di seluruh Indonesia. Pembasmian PKI tersebut, juga diiringi dengan penyebaran propaganda hitam terhadap PKI. Propaganda hitam yang manipulatif itu menyatakan bahwa organisasi yang berafiliasi dengan PKI, yaitu Pemuda Rakyat, dengan Gerwani (Gerakan Wanita Indonesia), melakukan penyiksaan dan pembunuhan brutal terhadap para perwira Angkatan Darat di Lubang Buaya (Mortimer, 2006: 389).

Angkatan Darat di bawah pimpinan Suharto, resmi mengambil alih kekuasaan dari tangan Presiden Sukarno, pada tanggal 11 Maret 1966, melalui Surat Perintah Sebelas Maret (Supersemar). Berbekal Supersemar ini juga, Suharto membubarkan PKI, dengan surat Keputusan Presiden No.1/3/1966 tanggal 12 Maret 1966. Surat keputusan presiden itu ditandatangani sendiri oleh Suharto. Pengambil alihan kekuasaan oleh Angkatan Darat di bawah kepemimpinan Suharto terhadap Sukarno, adalah sebuah kudeta yang bersifat perlahan, atau kudeta merangkak (Wardaya, 2007: 111-112).

Kehidupan politik Indonesia pasca pengambilalihan kekuasaan oleh Suharto, berubah drastis. Suharto dan militer berkuasa penuh tanpa ada pihak yang menandingi selayaknya pada masa pemerintahan 
Sukarno. Kekuasaan pada masa Orde Baru, terpusat pada Suharto dan orang-orang militer yang merupakan lingkaran inti Suharto (Ricklefs, 2001: 356). Golongan Karya (Golkar) adalah kendaraan politik Suharto dan militer untuk mendominasi perpolitikan Indonesia melalui pemilihan umum (Ricklefs, 2001:360).

Bidang ekonomi di Indonesia menjadi sebuah negara yang terbuka pada modal asing. Dasar hukum dari keterbukaan ini adalah Undang-Undang tahun 1967, tentang penanaman modal asing, Undang-undang No. 6 tahun 1968, tentang penanaman modal dalam negeri, dan Undang-undang No. 11 tentang pertambangan. Ketiga undang-undang ini disahkan oleh Suharto bahkan sebelum ia resmi menjabat sebagai presiden Republik Indonesia (Yuriandi, 2010: 3). Keterbukaan pada modal asing ini menyebabkan perekonomian Indonesia menjadi tidak mandiri dan sumber daya alam Indonesia, bisa dieksploitasi oleh kapitalisme internasional dengan leluasa (Caldwell \& Utrecht, 2011:291).

\section{FILSAFAT SEJARAH MARXISME}

Pandangan filsafat sejarah Marx disebut dengan materialisme dialektis atau materialisme historis, yang dipengaruhi oleh filsafat Hegel. Hegel berpandangan bahwa roh objektif menyatakan diri paling kuat dalam negara. Ini dikarenakan negara memiliki kehendak dan dapat bertindak. Dalam filsafat sejarah, Hegel memperlihatkan bagaimana manusia semakin menyadari kebebasannya dengan mengorganisir dirinya dan menjunjung tinggi kebebasannya (Suseno, 2001: 59).

Materialisme Marx bertitik tolak dari kritiknya terhadap materialisme Feuerbach. Feuerbach berpendapat bahwa bukan Tuhan yang menciptakan manusia, tetapi sebaliknya, manusia adalah yang menciptakan ide tentang Tuhan. Agama bagi Feuerbach hanyalah proyeksi pikiran manusia. Tuhan, malaikat, surga, neraka bagi Feuerbach, bukan merupakan kenyataan, melainkan hanya gambar yang bentukan manusia tentang dirinya sendiri. Oleh karena itu, agama hanyalah imajinasi manusia belaka. Agama bagi Feuerbach adalah cerminan hakikat manusia belaka (Suseno, 2001:68). Tuhan merupakan pikiran manusia 
yang pertama selanjutnya nalar, manusia, yang terakhir adalah pikiran manusia. Feuerbach memandang bahwa yang dianggap manusia sebagai Tuhan itu adalah hakikat dirinya sendiri (Plekhanov, 2002:21-22).

Marx memandang bahwa Feuerbach telah memperlihatkan keterbalikan subjek dan objek dalam filsafat Hegel. Bagi Hegel, roh atau ide yang menggerakkan sejarah, masyarakat, dan manusia, sementara bagi Feuerbach, Tuhan, roh, dan lain sebagainya itu hanyalah cerminan dari pemikiran manusia (Suseno, 2001: 71). Akan tetapi, Marx mengkritik materialisme Feuerbach. Menurut Marx dalam Theses on Feuerbach, konsep Feuerbach tentang manusia adalah bukan manusia yang nyata, melainkan bersifat abstrak dan subjektif. Selain itu, Feuerbach menurut Marx, tidak memahami pentingnya arti revolusioner sebagai sebuah aktivitas kritis. Artinya materialisme Feuerbach hanyalah bersifat kontemplatif belaka dan tidak bersifat revolusioner. Menurut Marx, Feuerbach tidak melihat bahwa agama adalah produk masyarakat (Marx dalam Marx \& Engels, 1998: 569-571).

Materi dalam pandangan Marx adalah kondisi ekonomi masyarakat manusia, yang dalam hal ini adalah corak produksi. Seperti yang disampaikan Marx dalam pengantar buku A Contribution to the Critique of Political Economy:

"In the social production which men carry on they enter into definite relations that are indispensable and independent of their will, these relations of production correspond to a definite stage of development of their material powers of production. The sum total of these relations of production constitutes the economic structure of society the real foundation, on which rise legal and political superstructures and to which correspond definite forms of social consciousness. The mode of production in material life determines the general character of the social, political and spiritual processes of life. It is not the consciousness of men that determines their existence, but, on the contrary, their social existence determines their consciousness" (Marx, 1904:11).

Materi menurut Marx merupakan cara manusia memproduksi sesuatu sebagai pemenuhan kebutuhan hidupnya. Corak produksi ter- 
diri atas hubungan-hubungan produksi (hubungan kooperatif atau distribusi kerja antarmanusia yang terlibat dalam proses produksi) dan tenaga-tenaga produktif (Kekuatan-kekuatan yang digunakan masyarakat untuk bekerja dan mengubah alam, yang terdiri atas, alat-alat kerja, manusia dengan keahlian masing-masing dan pengalaman-pengalaman dalam produksi (teknologi) (Suseno, 2001:143). Salah seorang Marxis, yaitu Mao Tse-Tung, berpandangan bahwa gerak materi bersifat dialektis. Dialektika materi ini dideskripsikannya dalam konsep "kontradiksi". Hukum kontradiksi menurut Mao adalah,

"The law of contradiction in things, that is, the law of the unity of opposites, is the basic law of materialist dialectics... There is internal contradiction in every single thing, hence its motion and development. Contradictoriness within a thing is the fundamental cause of its development, while its interrelations and interactions with other thing are secondary cause" (Mao, 1966:23-26).

Penyebab berbagai perubahan dalam pandangan filsafat dialektika materialis, adalah kontradiksi-kontradiksi internal dalam segala sesuatu itu sendiri. Berbagai perubahan sosial terwujud karena adanya perkembangan kontradiksi-kontradiksi internal suatu masyarakat itu sendiri. Kontradiksi tersebut adalah antara tenaga produktif dengan hubungan produksi, kontradiksi antara kelas sosial satu dan lainnya, yang terakhir adalah kontradiksi antara yang baru dan lama. Pertumbuhan berbagai kontradiksi inilah yang memajukan masyarakat dan mendorong proses perubahan masyarakat lama menjadi masyarakat baru (Mao, 1966:27-28).

Kontradiksi dalam dialektika materialis, bersifat umum atau mutlak. Maknanya, kontradiksi adalah suatu hal yang mutlak ada dalam eksistensi sesuatu. Keumuman atau kemutlakan kontradiksi mempunyai makna ganda. Pertama, ialah bahwa kontradiksi selalu ada di dalam proses perkembangan kenyataan, kedua, ialah bahwa pada setiap proses perkembangan dalam kenyataan terdapat gerak kontradiksi dari awal sampai akhir (Mao, 1966:30). Selain bersifat umum (mutlak), kontradiksi juga bersifat khusus (relatif), artinya bahwa dalam semua bentuk atau gerak selalu terdapat kontradiksinya yang bersifat khusus. 
Kontradiksi khusus ini adalah hakikat khusus yang membedakan sebuah kenyataan dari kenyataan lainnya (Mao,1966:35). Keumuman dan kekhususan kontradiksi memiliki hubungan yaitu hubungan antara watak umum dan individual, kontradiksi. Makna dari watak umum adalah bahwa kontradiksi berada dan berlangsung dalam semua proses dari awal sampai akhir. Baik itu dalam gerak, kenyataan, ataupun pikiran. Dengan demikian, kontradiksi adalah hal yang mutlak ada dalam kenyataan.

Kontradiksi kelas dalam sejarah masyarakat, menurut perspektif Marxisme, adalah perwujudan dari kekhususan kontradiksi (Mao, 1966: 69). Kontradiksi kelas, adalah hal yang selalu ada dalam masyarakat, dari mulai komune primitif, zaman perbudakan, feodalisme, kapitalisme dan terakhir sosialisme. Kontradiksi kelas ini akan berakhirjika fase masyarakat komunis dicapai, dan dengan demikian negara sebagai alat peredam kontradiksi akan melenyap. Marxisme menganggap bahwa perubahan masyarakat lama ke masyarakat baru selalu didasarkan atas revolusi. Hal ini disebabkan oleh sifat revolusioner dari kekuatan produktif (manusia dan alat kerja), sifat kontra revolusioner dari hubungan produksi. Revolusi yang melahirkan hubungan produksi baru, terjadi karena ketidakmampuan hubungan produksi memberikan respon atas kekuatan produktif (Pembebasan, Nomor 17 Maret 2000:5).

Dasar filsafat Marxisme adalah materi. Materi dalam perspektif Marxisme merupakan kondisi sosial dan ekonomi , khususnya corak produksi yang terdiri atas hubungan produktif dan kekuatan produktif. Setiap proses perkembangan sejarah selalu ditandai oleh "kontradiksi" antara kedua unsur corak produksi ini. Hal ini kemudian menjadi pembeda konsep materialisme dialektis atau materialisme historis Marxisme dengan dialektika Hegel atau Materialisme Feuerbach. Hegel berpandangan bahwa dasar dialektika sejarah adalah ide atau roh absolut. Materialisme Feuerbach, berpandangan bahwa manusia terlepas dari masyarakat, Tuhan, dan agama bagi Feuerbach adalah cerminan manusia secara individual. Bagi Marx, ide-ide tentang keagamaan, politik, budaya, atau suprastruktur adalah cerminan dari sistem ekonomi atau basis struktur. Sistem ekonomi dalam perspektif Marx- 
isme adalah terkait dengan cara manusia berproduksi atau corak produksi. Sejarah bagi Marx, adalah bukan hanya sejarah para tokoh yang menonjol atau orang-orang besar, melainkan adalah sejarah kelaskelas sosial yang saling bertentangan. Kelas-kelas sosial yang saling bertentangan tersebut adalah kelas penindas dan kelas tertindas, seperti yang ditulis oleh Marx dan Engels dalam Manifesto of the Communist Party, "Hitherto, every form of society has been based, as we have already seen, on the antagonism of oppressing and oppressed classes" (Marx \& Engels, 1970: 46).

\section{GERAKAN 30 SEPTEMBER 1965 DITINJAU DARI FILSAFAT SEJARAH MARXISME}

Masyarakat Indonesia pada masa pemerintahan Sukarno, adalah masyarakat kapitalis, nampak kelas-kelas sosial yaitu kelas borjuis militer dan kelas proletariat. Seperti halnya pandangan filsafat Hegel, filsafat sejarah Marxisme memandang bahwa sejarah berlangsung secara dialektis.

Proses dialektika sejarah masyarakat Indonesia pada masa pemerintahan Sukarno menjadi tesis, adalah kelas proletariat yang diwakili oleh PKI. PKI berdiri tahun 1920, pada masa kolonial Belanda. Pada tahun 1926, PKI melancarkan pemberontakan terhadap pemerintah kolonial Hindia Belanda, di Pulau Jawa. Sementara, di Pulau Sumatera, PKI memberontak pada tahun 1927. Pemberontakan ini mengakibatkan ribuan anggota PKI ditangkap dan dibuang oleh pemerintah kolonial Hindia Belanda, ke Boven Digul, Papua Barat (Caldwell \& Utrecht, 2011: 129). Selanjutnya, dalam proses dialektika sejarah masyarakat Indonesia, pada masa pemerintahan Sukarno, yang menjadi antitesis adalah kelas borjuis, yang diwakili oleh militer Indonesia/ TNI. Kemudian, yang menjadi sintesis dalam proses dialektika tersebut, adalah naiknya Jenderal Suharto ke puncak kekuasaan, yang menjadi tonggak awal berdirinya rezim Orde Baru. Walaupun sedikit berbeda dengan filsafat sejarah Marxisme, yang memandang bahwa kontradiksi antara borjuis dan proletariat akan menghasilkan masyarakat tanpa kelas atau komunisme, perbedaan tersebut tidaklah menegasikan pandangan Marx tentang sejarah, tersebut. Kapitalisme 
pada masa pemerintahan Sukarno, belumlah matang, ketidakmatangan kapitalisme dalam pemerintahan Sukarno, terlihat pada suprastruktur atau sistem politik pemerintahan Sukarno. Sistem politik pada masa pemerintahan Sukarno, meniadakan demokrasi, pemilu ditiadakan, militer belum berkuasa secara penuh, walaupun telah memiliki kekuasaan yang dominan. Oleh karena itulah, naiknya Suharto menyempurnakan kekuasaan militer dan mematangkan sistem kapitalisme dalam masyarakat Indonesia.

Berkuasanya militer secara penuh pada masa rezim Orde Baru Suharto, tidak terlepas dari kondisi masyarakat kapitalisme pada masa pemerintahan Sukarno. Kelas borjuis militer, berisikan orang-orang dari kalangan militer yang mendapat hak atas pengelolaan berbagai industri milik kolonial Belanda yang dinasionalisasikan pada tahun 1957. Hak ini mereka dapatkan berdasarkan undang-undang darurat militer/perang pada tahun 1957, yang menjadi legalisasi besarnya kontrol militer terhadap sistem ekonomi politik Indonesia.

Kontradiksi dalam masyarakat Indonesia yang kapitalis agak sedikit rumit. Kontradiksi pokok pada dasarnya tetap antara borjuis dan proletariat. Kelas borjuis diwakili oleh TNI, yang menguasai industri-industri kolonial Belanda yang telah dinasionalisasikan, sementara, kelas proletariat diwakili oleh PKI. Kedua kubu ini saling bertarung dalam gelanggang politik. PKI dan TNI, memiliki akses atas kekuasaan, kedua kubu ini memiliki menteri-menteri di pemerintahan Sukarno. Selain itu, mereka juga memiliki kursi di parlemen. Hanya saja, secara politik dan ekonomi, kekuasaan TNI lebih besar dibanding PKI. Hal ini disebabkan oleh keberadaan undang-undang darurat militer tahun 1957. Atas dasar undang-undang ini, para panglima Angkatan Darat memiliki kekuasaan untuk membatasi kebebasan pers, menjebloskan tokoh-tokoh politik ke dalam tahanan, menerapkan undang-undang tak tertulis milik mereka, dan yang penting adalah kontrol manajerial terhadap industri-industri/perusahaan-perusahaan (Roosa, 2008: 261).

Sukarno, yang merupakan presiden Republik Indonesia, berada di tengah-tengah kontradiksi antara PKI dan TNI Angkatan Darat ini. Sukarno pada kenyataannya memanfaatkan dukungan PKI terhadap- 
nya, sebagai alat untuk memperkuat posisi tawarnya ketika berhadapan dengan TNI, khususnya TNI Angkatan Darat. Dengan dukungan PKI yang memiliki kekuatan massa besar, terhadap Sukarno, Angkatan Darat akan berpikir panjang untuk menjatuhkan Sukarno dari kekuasaan (Roosa, 2008: 297). Di sisi lain, Sukarno juga sepakat dengan TNI, terkait keberadaan parlemen dan pemilu yang demokratis. Dekrit Presiden tahun 1959 adalah wujud dari konsesi antara Sukarno dan TNI. Pembubaran parlemen, dan penghapusan pemilu yang demokratis, adalah dampak dari pemberlakuan dekrit presiden tersebut. Keberadaan Sukarno mendamaikan untuk sementara, kontradiksi yang seharusnya tak terdamaikan dalam masyarakat kapitalis, yaitu kontradiksi antara borjuis dan proletariat.

Pasca G30S 1965, kekuasaan Sukarno secara perlahan diambil alih oleh TNI Angkatan Darat. Suharto adalah pemimpin dari kudeta merangkak tersebut. TNI Angkatan Darat tidak berani secara terangterangan melakukan kudeta terhadap Presiden Sukarno, oleh karena itulah mereka melakukan kudeta merangkak, atau dengan berkedok tindakan pembasmian terhadap sebuah gerakan yang dituduh sebagai gerakan kudeta (G30S 1965). G30S 1965, kemudian dibesar-besarkan oleh Suharto, dengan stigma sebagai sebuah tindakan pengkhianatan terhadap ideologi Pancasila dan pemerintahan Sukarno. Surat perintah sebelas maret (Supersemar) adalah legalisasi dari pengambil alihan kekuasaan oleh TNI Angkatan Darat dari tangan Sukarno. Supersemar adalah surat perintah harian dari Presiden Sukarno terhadap Letnan Jenderal Suharto. Sebenarnya isi perintah Presiden Sukarno terhadap Letjen Suharto dalam Supersemar, adalah supaya Suharto "mengambil segala tindakan yang dianggap perlu", tujuannya adalah untuk "terjaminnya keamanan dan ketenangan serta kestabilan jalannya pemerintahan dan jalannya revolusi" (Wardaya, 2007: 16-17). Akan tetapi, Suharto menggunakan wewenang yang didapatnya dari Supersemar untuk membubarkan PKI, menangkap para menteri dan pendukung Sukarno. Bahkan pada akhirnya, Suharto dan TNI Angkatan Darat, berhasil menjatuhkan Sukarno dari puncak kekuasaan (Wardaya, 2007: 18). Setelah Sukarno jatuh, Suharto dan TNI Angkatan Darat, bersama kapitalisme internasional, menyempurnakan sistem kapitalisme da- 
lam masyarakat Indonesia. G30S 1965 menandai kehancuran PKI sebagai partai proletariat.

Masyarakat kapitalis dalam pandangan Marxisme adalah masyarakat yang di dalamnya terdapat kemerdekaan modal, perdagangan bebas, bebas menjual dan bebas membeli (Marx \& Engels, 1970: 50). Kemerdekaan modal ini hanya bisa didapat di bawah pemerintahan yang berpihak pada kemerdekaan modal.

Pemerintahan Sukarno, adalah pemerintahan yang menghalangi kemerdekaan modal, khususnya modal asing. Kebijakan nasionalisasi perusahaan/industri asing, penolakan terhadap regulasi IMF, dan penolakan terhadap bantuan asing, adalah contoh kebijakan yang menghalangi gerak modal. Kebijakan ekonomi berdikari, pemerintahan Sukarno, menghalangi infiltrasi modal asing ke Indonesia. Masa Orde Baru, adalah antitesis dari masa pemerintahan Sukarno. Di bawah rezim Orde Baru, modal asing bisa bergerak dengan leluasa. Regulasi IMF diterapkan untuk mendapatkan bantuan. Regulasi IMF tersebut adalah penghapusan subsidi rakyat, liberalisasi investasi asing, liberalisasi impor, yang mengakibatkan pasar dalam negeri Indonesia dibanjiri produk impor (Caldwell \& Utrecht, 2011:287).

Liberalisasi ekonomi pada masa Orde Baru, kemudian menuai protes dari kalangan mahasiswa dan pemuda, pada saat kunjungan Perdana Menteri Jepang, Tanaka Kakuei, tahun 1974. Protes tersebut terkenal dengan nama Malari (Malapetaka Lima Belas Januari). Protes ini kemudian berujung pada kerusuhan, yaitu pembakaran dan perampokan ratusan gedung dan toko yang menjual produk-produk Jepang (Ricklefs, 2001: 362). Dasar dari protes mahasiswa dan pemuda pada Malari, adalah kenaikan harga dan pengangguran, kegagalan perbaikan dalam layanan sosial, kebangkrutan perusahaan nasional ketika berhadapan dengan perusahaan asing. Selain itu, protes mahasiswa dan pemuda, didasari oleh maraknya perampasan terhadap para petani (Caldwell \& Utrecht, 2011: 319). Protes terutama dialamatkan pada Jenderal Ali Murtopo dan Mayjend Sudjono Humardani, terkait peran mereka sebagai perantara antara pemerintah dan investor asing, khususnya investor Jepang (Ricklefs, 2001: 362).

Protes mahasiswa dan pemuda pada tahun 1974, didukung oleh 
salah satu faksi dalam tubuh TNI Angkatan Darat, yaitu Komandan Kopkamtib (Komando Operasi Pemulihan Keamanan dan Ketertiban), Jenderal Sumitro. Jenderal Sumitro termasuk dalam salah satu faksi militer, yang tidak puas dengan liberalisasi investasi asing, yang pada prakteknya menguras sumber daya alam Indonesia. Selain mendukung protes mahasiswa dan pemuda, Jenderal Sumitro memperbolehkan demonstrasi mahasiswa anti Tanaka. Suharto, kemudian meminta Ali Murtopo dan Sudjono Humardani mengundurkan diri. Jenderal Sumitro yang tidak berani mengambil alih kekuasaan dari tangan Suharto, kemudian diminta mengundurkan diri sebagai Komandan Kopkamtib dan selanjutnya ia dipecat dari jabatannya sebagai Wakil Komandan Angkatan Bersenjata (Caldwell \& Utrecht, 2011: 321-322).

Pada masa Orde Baru, proletariat tidak terwakili dalam satu organisasi tertentu, sebagaimana pada zaman pemerintahan Sukarno. Hal ini disebabkan oleh pembatasan kebebasan berserikat dan berpolitik bagi proletariat di Indonesia, oleh rezim Orde Baru (Istakhori, 2008: 1). Selain itu, dengan keberadaan TAP MPRS No. XXV/1966, Marxisme sebagai ideologi proletariat dan PKI sebagai partai proletariat, dinyatakan terlarang. Liberalisasi ideologi, pada prakteknya ditiadakan pada masa Orde Baru. Hal ini terlihat dengan diberlakukannya asas tunggal Pancasila sebagai satu-satunya ideologi bagi semua organisasi. Selanjutnya, manifestasi dari pembatasan kebebasan berserikat bagi rakyat, adalah dengan diciptakannya organisasi massa (ormas) yang menjadi kepanjangan tangan rezim Orde Baru. Ormas-ormas tersebut adalah, KNPI untuk pemuda, SPSI untuk buruh, Korpri untuk pegawai negeri, HKTI untuk petani, HNSI untuk nelayan, KADIN untuk majikan, HIPMI untuk pengusaha muda, Dharma Wanita untuk istri-istri pegawai negeri, PWI untuk jurnalis, Golkar (Golongan Karya), PPP (Partai Persatuan Pembangunan), dan PDI (Partai Demokrasi Indonesia) untuk partai politik, dan lain-lain (Rahman, 2006:42-43).

Liberalisasi ekonomi pada awal berdirinya rezim Orde Baru, dalam perkembangannya kemudian berubah menjadi kapitalisme monopoli yang terpusat pada kroni dan keluarga Suharto. Korupsi dan penyalahgunaan kekuasaan, semakin ekstrim dipraktekkan oleh rezim Orde Baru. Krisis keuangan Asia, kemudian menyebabkan Indonesia 
terjerumus ke dalam bencana ekonomi. Krisis ekonomi dan politik kemudian menyebabkan Rezim Orde Baru Suharto runtuh pada tahun 1998, di tengah maraknya protes mahasiswa dan rakyat yang menuntut pengunduran diri Suharto sebagai presiden (Ricklefs, 2001: 387). Dari uraian tentang rezim Orde Baru tadi, bisa ditarik kesimpulan bahwa masa Orde Baru adalah masa kejayaan kapitalisme liberal. Investor asing memiliki keleluasaan untuk menanamkan modal dan memasarkan hasil produksi di Indonesia. Akan tetapi, liberalisasi ekonomi ini tidak diikuti oleh liberalisasi di bidang politik dan ideologi. Akibatnya adalah proletariat tidak memiliki wadah organisasi untuk menyalurkan aspirasi dan memperjuangkan hidupnya. Liberalisasi ekonomi pada masa Orde Baru kemudian bermetamorfosa menjadi kapitalisme monopoli yang korup, modal dan kekuasaan hanya terpusat pada keluarga dan kroni Suharto belaka. Hal inilah yang kemudian ikut mendorong kejatuhan rezim Suharto pada tahun 1998, ketika Indonesia terperosok dalam bencana ekonomi sebagai dampak dari krisis keuangan Asia.

Pada masa Orde Baru, terjadi perubahan dalam bidang politik, jika dibandingkan dengan masa pemerintahan Sukarno. Pemilihan umum diadakan kembali, walaupun pada prakteknya penuh rekayasa. Hal ini berbeda dengan peniadaan pemilu pada masa pemerintahan Sukarno atau masa demokrasi terpimpin. Akan tetapi, terdapat persamaan antara masa Orde Baru dengan masa pemerintahan Sukarno. Persamaan tersebut adalah terletak pada kekuasaan presiden yang besar. Pada masa Orde Baru dan pemerintahan Sukarno, parlemen tunduk pada presiden. Kekuasaan presiden yang besar ini adalah konsekuensi dari penerapan UUD (Undang-Undang Dasar) 1945, dalam bidang politik.

\section{SIMPULAN}

Berdasarkan atas uraian dan analisis pada empat bab sebelumnya, bisa ditarik kesimpulan bahwa, pertama, hakikat sejarah menurut Marxisme, adalah kontradiksi. Kedua, filsafat sejarah Marxisme sangat relevan untuk memahami latar belakang ekonomi politik gerakan 30 September 1965. Dengan menggunakan perspektif Marxisme dalam 
memandang G30S 1965, maka pemahaman bahwa esensi dari gerakan 30 September 1965, adalah manifestasi dari kontradiksi kelas dalam masyarakat kapitalisme, bisa didapat. Ketiga, G30S 1965, adalah sebuah operasi militer yang dijadikan dalih oleh kubu anti PKI dan Sukarno, untuk mengambil alih kekuasaan politik dari tangan Sukarno. Keempat, Sebelum G30S 1965, masyarakat Indonesia adalah masyarakat kapitalis. Hal ini terlihat dari kelas-kelas sosial dalam corak produksi masyarakat Indonesia. Kelima, sebelum G30S 1965, militer/TNI memiliki kekuasaan besar dalam bidang politik dan ekonomi di Indonesia. Keenam, Sukarno adalah kekuatan penyeimbang dari kontradiksi antara borjuis yang diwakili oleh TNI dan proletariat, yang diwakili oleh PKI.

\section{DAFTAR PUSTAKA}

Anderson, B and Mc Vey, R,T, 2009, A Preliminary Analysis of the October 1, 1965, Coup in Indonesia, Equinox Publishing (Asia), Singapore.

Caldwell, M dan Utrecht, E., 2011, Sejarah Alternatif Indonesia, Terjemahan Indonesia, Diterjemahkan oleh Saut Pasaribu, Djaman Baroe, Yogyakarta.

Bakker, A dan Zubair, C.,1990, Metode Penelitian Filsafat, Kanisius, Yogyakarta.

Copleston, F, 1963, A History of Philosophy, Volume VII, Modern Philosophy: From the Post-Kantian Idealists to Marx, Kierkegaard, and Nietzsche, Doubleday, New York.

Crouch, H, 2007, The Army and Politics in Indonesia, Equinox Publishing (Asia), Singapore.

Elster, J, 1986, An Introduction to Karl Marx, Cambridge University Press, Cambridge, United Kingdom.

Engels, F, 1908, Socialism: Utopian and Scientific, Diterjemahkan oleh Edward Aveling, Charles H. Kerr \& Company, Chicago. 1946, Dialectics of Nature, Diterjemahkan Oleh Clemens Dutt, Lawrence And Wishart, LTD, London. 1976, Ludwig Feuerbach and the End of Classical German Philosophy, Foreign Language Press, Peking. 
Fromm, E., 2001, Konsep Manusia Menurut Marx, Diterjemahkan Oleh Agung Prihatoro, Pustaka Pelajar, Yogyakarta.

Hadimadja dan Dwipayana, 1989, Soeharto, Pikiran, Ucapan, dan Tindakan Saya, Citra Lamtoro Gung Persada, Jakarta.

Hadiwijono, H., 1980, Sari Sejarah Filsafat Barat 2, Kanisius, Yogyakarta.

Hardiman, B.F., 2004, Filsafat Modern Dari Machiavelli Sampai Nietzsche, PT Gramedia Pustaka Utama, Jakarta.

Haryadi, E., 2000, Lenin: Pikiran Tindakan dan Ucapan, Komunitas Studi Untuk Perubahan, Jakarta.

Hatta, M, 1963, Persoalan Ekonomi Sosialis Indonesia, Djambatan, Jakarta.

Hegel, G.W.F., 2001, The Philosophy of History, Diterjemahkan Oleh J. Sibree M.A, Batoche Books, Kitchener Ontario Canada.

Kahan, Z, 1918, Karl Marx: His Life and Teaching, British Socialist Party, London.

Kusumandaru, K.B, 2004, Karl Marx, Revolusi Dan Sosialisme, Resist Book, Yogyakarta.

Lane, M, 2012, Malapetaka di Indonesia: Sebuah Esei Renungan Tentang Pengalaman Sejarah Gerakan Kiri, Djaman Baroe, Yogyakarta.

Lenin, V, I, 1976, The State and Revolution, Foreign Language Press, Peking.

MABES ABRI, 1995, Bahaya Laten Komunisme Di Indonesia, Pusat Sejarah dan Tradisi ABRI, Jakarta.

Mao,T.T., 1966, Four Essays on Philosophy, Diterjemahkan Oleh Komite untuk Publikasi Karya-Karya Terpilih Mao Tse Tung, Foreign Language Press, Peking.

Marx, K, 1904, A Contribution To The Critique of Political Economy, Charles H Kerr \& Company, Chicago.

1970, Critique of Hegel's Philosophy of Right, Oxford University

Press, England.

1972, The Eighteenth Brumaire of Louis Bonaparte, Progress Publishers, Moscow.

2009, The Civil War in France, Diterjemahkan oleh Friedrich Engels, Dodo Press, UK.

Marx, K, \& Engels, F, 1970, Manifesto of The Communist Party, Foreign 
Language Press, Peking. 1987, Karl Marx, Frederick Engels: Collected Works, Progress Publishers, Moscow. 1998, The German Ideology, Prometheus Books, New York.

Mortimer, R, 2006, Indonesian Communism Under Sukarno, Ideology and Politics, 1959-1965, Equinox Publishing (Asia), Singapore.

Osborne, R., 2001, Filsafat Untuk Pemula, Kanisius, Yogyakarta.

Plekhanov, G., 2002, Masalah-Masalah Dasar Marxisme, Diterjemahkan oleh Ira iramanto, Hasta Mitra, Jakarta.

Pour, J, 2011, Gerakan 30 September, Pelaku, Pahlawan dan Petualang, PT. Kompas Media Nusantara, Jakarta.

Rahman, M, F, 2006, Democracy Without The Democrats, CV. Dunia Printing Selaras, Jakarta.

Ricklefs, M.C., 2001, A History Of Modern Indonesia Since C. 1200, Palgrave, Great Britain.

Rizky, A \& Majidi, N, 2008, Neoliberalisme Mencengkeram Indonesia, E. Publishing Company, Jakarta.

Roosa, John, 2008, Dalih Pembunuhan Massal, Gerakan 30 September dan Kudeta Soeharto, Hasta Mitra, Jakarta.

Russell, B., 1955, History of Western Philosophy and its Connection with Political and Social Circumstances from the Earliest Time to the Present Day, George Allen \& Unwin Ltd, London.

Sekjend MPR RI, 2011, Undang Undang Dasar Negara Republik Indonesia Tahun 1945, Sekretariat Jenderal MPR RI, Jakarta.

Setneg R.I, 1994, Gerakan 30 September, Pemberontakan Partai Komunis Indonesia, Latar Belakang, Aksi, dan Penumpasannya, Sekretariat Negara Republik Indonesia, Jakarta.

Soekarno, 1964, Di Bawah Bendera Revolusi, Panitya Penerbit Di Bawah Bendera Revolusi, Jakarta.

Sudisman, 2005, Pledoi Sudisman Politbiro CC PKI, Edi Cahyono's Experience, Tanpa Tempat.

Suseno, F.M., 2001, Pemikiran Karl Marx dari Sosialisme Utopis ke Perselisihan Revisionisme, PT Gramedia Pustaka Utama, Jakarta. 
Tamburaka, R, E, 1999, Pengantar Ilmu Sejarah, Teori Filsafat Sejarah, Sejarah Filsafat, dan IPTEK, Rineka Cipta, Jakarta.

Wardaya, B, T, 2007, Membongkar Supersemar, dari CIA Hingga Kudeta Merangkak Melawan Bung Karno, Galangpress, Yogyakarta.

\section{Koran/Majalah}

Pembebasan., 2000 No 17, Edisi Maret, hal:5 - 8.

\section{Makalah}

Istakhori, K, 2008, Membangun Kemandirian Sikap Politik Gerakan Buruh Indonesia Melawan Neoliberalisme, disampaikan dalam Diskusi Panel Buruh dan Politik, Konferensi Warisan Otoriterianisme, tanggal 6 Agustus di UI Depok.

Yuriandi, A, 2010 Penanaman Modal Asing Pada Masa Pemerintahan Orde Lama dan Pemerintahan Orde Baru, Makalah Mahasiswa Sekolah Pascasarjana Universitas Sumatera Utara, Medan.

\section{Situs Internet}

http://id.wikipedia.org/wiki/Dewan_Revolusi_Indonesia, akses 18/7/ 2013, pukul18.23 WIB

http://whintjie.blogspot.com/2011/05/aset-koruptor-indonesia-di-si nga pura.html, akses 20/7/2013, pukul2.17 WIB id.wikipedia.org, diakses tanggal 7/12/2011, jam 8.41 WIB 